\title{
THE APPLICATION OF FORMATIVE MODEL PROCEDURES TO ASSESS THE QUALITY OF MEASUREMENTS: THE CASE OF JOB EMBEDDEDNESS' DIMENSIONS
}

\author{
Gugup Kismono \\ Faculty of Economics and Business Universitas Gadjah Mada \\ e-mail: gugupkismono@yahoo.com
}

\begin{abstract}
Job embeddedness as a contemporary model of voluntary turnover has attracted attention from scholars and researchers. This model has been claimed to be more powerful in explaining employee voluntary turnover than the traditional models. Based on the taxonomy of multidimensional constructs, job embeddedness should be an aggregate model. The aggregate model requires that the construct (job embeddedness) are caused by indicators. As a consequent, job embeddedness should be classified within a formative measurement model. However, the evaluation of the job embeddedness measurements, so far, utilised reflective model procedures. Since job embeddedness is formative or causal indicators, construct misspecification error may occur. This study offered an alternative method yet suitable to assess the dimensions of job embeddedness measurement quality. The results showed that treating job embeddedness as reflective model may not be suitable.
\end{abstract}

Keywords: job embeddedness, voluntary turnover, formative model, reflective model, misspecification.

\begin{abstract}
Abstrak
"Kelekatan pekerjaan" (job embeddedness) sebagai sebuah model kontemporer perputaran karyawan menarik perhatian para ilmuwan dan peneliti. Model ini telah dipandang lebih unggul dibanding model tradisional dalam menjelaskan perputaran sukarela karyawan. Berdasarkan pada taksonomi konstruk multidimensional, kelekatan pekerjaan harus diperlakukan sebagai model agregat. Model agregat mensyaratkan bahwa sebuah konstruk dibentuk atau disebabkan (bukan menyebabkan) oleh indikator-indikator. Sebagai konsekuensinya, konstruk kelekatan pekerjaan harus diklasifikasikan ke dalam model alat ukur formatif. Namun demikian, sejauh ini evaluasi atas alat ukur kelekatan pekerjaan masih menggunakan prosedur model reflektif. Karena kelekatan pekerjaan merupakan konstruk formatif, penggunaan prosedur model reflektif untuk mengevaluasi alat ukurnya berpotensi menghasilkan kesalahan construct misspesification. Riset ini menawarkan metoda alternatif yang lebih sesuai untuk mengevaluasi kualitas alat ukur kelekatan pekerjaan, khususnya dimensi-dimensinya. Hasil riset menunjukkan bahwa penggunaan model reflektif tidak cocok. Hal ini ditunjukkan dengan adanya perbedaan hasil antara penggunaan model reflektif dan model formatif.
\end{abstract}

Kata kunci: kelekatan pekerjaan, perputaran sukarela karyawan, model formatif, model reflektif, misspecification.

\section{INTRODUCTION}

Turnover models to better understand the turnover process through which employees voluntarily leave an organisation have been developed for more than five decades (Price, 2004; Maertz and Griffeth, 2004; March and Simon, 1958). Even though positive aspects of volun- tary turnover have been well identified (Dalton et al., 1982; Mobley, 1982), it has long been assumed to pose serious negative consequences for the organisation as it may take the organisation by surprise and causes unplanned for disruption in operations (Boshoff and Mels, 2000). Furthermore, resignations may lead to lower 
productivity, loss of high performers (Mobley, 1982), separation, replacement, and training and development costs (Bannister and Griffeth, 1986; Pinkovitz et al., 2004; Griffeth and Hom, 2001; Koys, 2001), along with potential sales costs(Bliss , 2006).

Additionally, there are other turnover costs that are hidden and perhaps harder to measure. Examples include potential hidden costs inherent in trade secrets being given to competitors, loss of business opportunity to competitors, loss of corporate and job knowledge, temporary decrease in service quality, loss of potential future leaders (Griffeth and Hom, 2001), disruption of social and communication structures and subsequent negative public relations (Mobley, 1982), and perceived demoralization of those who remain in the organisation (Staw, 1980; Boshoff and Mels, 2000). Employees who leave their organization voluntarily may speak negative but secret aspects of their workplace. Given these consequences, the concept of employee voluntary turnover continues to attract attention of both researchers and practitioners.

Turnover models can be classified into two broad categories namely the core models or conventional/classical and alternative/contemporary models. However, the models have long been dominated by the core models (Steel, 2002). The core or traditional models focus on the role of some key factors namely job satisfaction, organizational commitment, behavioural intentions, and job search mechanisms in influencing voluntary turnover. However, research findings have consistently shown that job satisfaction, and organizational commitment play only small role in employee voluntary turnover (Mitchell et al., 2001b; Holtom and O'Neill, 2004; Griffeth et al., 2000). Additionally, measures derived from job search have little value as predictors of voluntary turnover (Steel, 2002).

The most recent theory to explain voluntary turnover process may be job embeddedness model, a concept focuses on why people choose to stay with a job rather than why they choose to leave a job. Job embeddedness is a broad constellation of job-related factors and non-job-related factors that keep a person from leaving her or his job (Mitchell et al., 2001b). According to Mitchell and colleagues (2001b), the critical aspects of job embeddedness are (1) the extent to which people have links to other people or activities at work or at home, (2) the extent to which their jobs and communities fit with the other aspects in their life spaces, and (3) the ease with which links can be broken, especially if they leaved their jobs and move to other cities or homes.

This new construct seems to be a much more powerful predictor of turnover intention, actual voluntary turnover, absenteeism, job performance and citizenship behaviour than traditional concepts. Job embeddedness is a powerful indicator because it accounts for more components of a person's life and includes nonwork factors not simply salary or whether or not a person feel happy with the job.

Mitchell and Lee (2001), Mitchell and associates (2001b), and Lee and colleagues (2004) asserted that job embeddedness is a multidimensional aggregate of the on-the-job and off-the-job forces that may prevent employee from leaving an organisation. Accordingly, the variable of job embeddedness was disaggregated into two major components; onthe-job embeddedness, and off-the-job embeddedness; and three dimensions that is fit, sacrifice, and links (Lee et al., 2004; Yao et al., 2004). On-the-job embeddedness is made up of organisation fit, organisation sacrifice, and organisation links. Off-the-job embeddedness is composed of community fit, community sacrifice, and community links (Yao et al., 2004).

Empirical findings showed that on-thejob embeddedness and off-the-job embeddedness significantly correlated with actual voluntary turnover (Lee et al., 2004). A previous research by Holtom and Lee (2001a), and Mitchell and Lee (2001) found that job embeddedness related to intention to leave and predicted subsequent actual voluntary turnover. These findings were shared by other researchers including Holtom and O'Neill (2004) and Cunningham et al. (2005).

The measurement of job embeddedness initially developed by Mitchell and associates (2001b). In general, reflective model principles, namely convergent validity and reliability test, were utilised to evaluate the quality of the measurement in previous studies. Since job embeddedness is formative or causal indicators, construct misspecification error may occur. As a result, the research findings that treated job 
embeddedness as a reflective construct might not be robust.

This study offered an alternative method yet suitable to assess job embeddedness measurement quality. Formative model procedures were applied to validate the measurement of job embeddedness using structural equation modelling with AMOS software.

The utilization of formative model procedures and structural equation modelling to evaluate job embeddedness causal indicators provided valuable contributions to the methodological aspect. Proper evaluation used in this study offered a different insight on how to validate job embeddedness indicators.

\section{Review on Job Embeddedness: Formative versus Reflective Model}

The validity and reliability tests done in previous research to evaluate the quality of job embeddedness measurement were derived from the concepts of a reflective model. It might be misleading. Based on the taxonomy of multidimensional constructs proposed by Law, Wong and Mobley (1998), job embeddedness should be an aggregate model. The aggregate model requires that the construct (job embeddedness) are caused by indicators. As a consequent, job embeddedness should be treated as a formative measurement model and needs different validation processes (Hair et al., 2006; MacKenzie et al., 2005; Diamantopoulos and Winklhofer, 2001). Internal consistency and convergent validity may not be useful validation criteria for formative indicators like job embeddedness (Diamantopoulos and Siguaw, 2006; Bollen and Lennox, 1991).

Figure 1 presented a general measurement (Structural Equation Modelling-SEM) model for job embeddedness. The measurement model of job embeddedness retains several important characteristics (Diamantopoulos and Winklhofer, 2001; MacKenzie et al., 2005; Jarvis et al., 2003; Coltman et al., 2007; Bollen and Lennox, 1991) including: 1) the direction of causality is from measures $(\mathrm{X} 1, \mathrm{X} 2, \mathrm{X} 3)$ to construct. 2) Indicators or items are modelled as causes of the latent variable (the construct). 3) Indicator correlations are not explained by the latent variable. 4) Measurement errors (e1, e2, e3) or disturbance (d) is modelled at the construct level. 5) Indicators or items are independent variables.

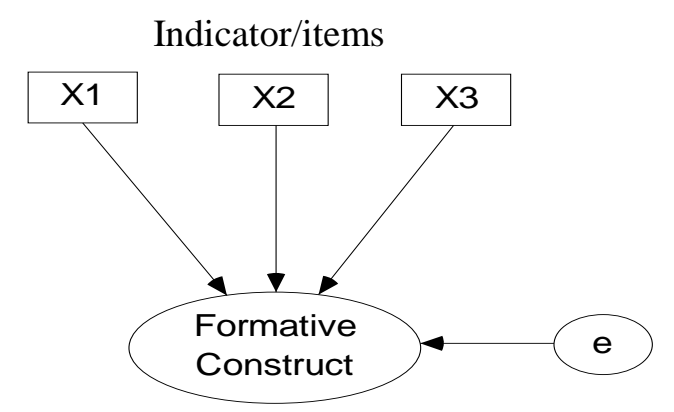

Figure 1: Measurement Model for Job Embeddedness as Formative Construct

The measurement (SEM) model of construct within a reflective model suggests different characteristics. As described in Figure 2 , several key features of the SEM model for reflective construct (MacKenzie et al., 2005; Diamantopoulos and Winklhofer, 2001; Jarvis et al., 2003; Coltman et al., 2007) include: 1) the direction of causality is from construct (latent variable) to measures (X1, X2, X3). 2) The indicators or items are modelled as effects of the latent variable. 3) Indicator correlations are explained by the latent variable. 4) A change in the latent variable will result in changes in all indicators. 5) Measurement errors (e1, e2, e3) or disturbance (d) is modelled at the item level. 6) Indicators or items are dependent variables.

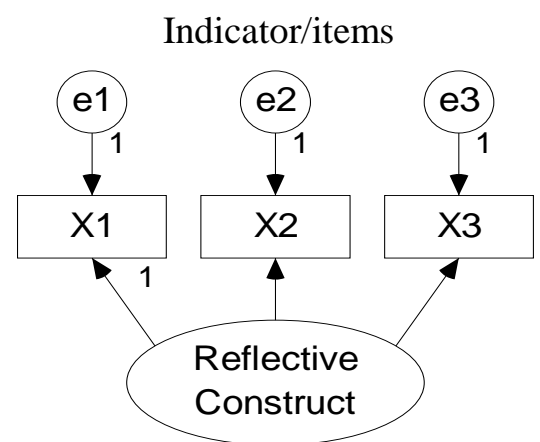

Figure 2: Measurement Model for Reflective Construct

In general, it is sufficient to measure the quality of reflective construct using convergent validity and reliability (or internal consistency) (Diamantopoulos and Winklhofer, 2001; MacKenzie et al., 2005). Convergent validity suggests the extent to which a set of measured items actually reflects the theoretical latent 
construct that these items are designed to measure (Hair et al., 2006). Factor loading is used to indicate the validity of the construct's measures. When items present adequate factor loadigs' values, the items can be judged as good measures (Hair et al., 2006). Internal consistency (reliability test) relates the individual measurement items to the relevant construct and hence should display high inter-correlation (Hair et al., 2006). The internal consistency was calculated using corrected item to total correlation and Cronbach's alpha measure. A high correlation of the items is desirable $(\mathrm{Bb}$ len and Lennox, 1991). This situation suggests that the measures are reliable; high reliability is represented by a high alpha score.

\section{Methods for Evaluating the Measurement of Job Embeddedness Using Formative Model Procedures}

In this research, the quality of job embeddedness items was tested using several steps as suggested by Diamantopoulos and Siguaw (2006), and Diamantopoulos and Winklhofer (2001). The first step was to conduct an assessment of multicollinearity among items within the constructs to measure organisation fit, organisation sacrifice, organisation links, community fit, community sacrifice and community links dimensions. High levels of multicollinearity among items made it difficult to separate the distinct impact of individual indicators on the construct or variable measured
(Bollen and Lennox, 1991). High multicollinearity among items might also suggest that the items give redundant information; hence it might be necessary to eliminate some items that were highly correlated. Subsequently, in the second step the remaining items from step one was correlated to the global item of the related construct. The complete list of items was presented in Appendix 1 and Appendix 2.

The global item was a broad or global question to measure respondents' overall perception on the constructs, and therefore it was assumed that the global item validly represents the construct. In this case, the global item was used to alternatively measure the construct. Since the global item was an alternative measure of the construct, correlating indicators to the global item were essentially comparable to conducting an external validation process (Diamantopoulos and Winklhofer, 2001). Thus, it was expected that high quality indicators were significantly correlated with the global item (Diamantopoulos and Winklhofer, 2001; Diamantopoulos and Siguaw, 2006). Any items with non-significant correlation coefficients should be removed. However, this step did not determine the contribution of individual indicators to the construct measured. Thus, in the third and fourth steps, the Multiple Indicators and Multiple Causes (MIMIC) model was utilised to assess if there was a significant contribution from any of the individual indicators.

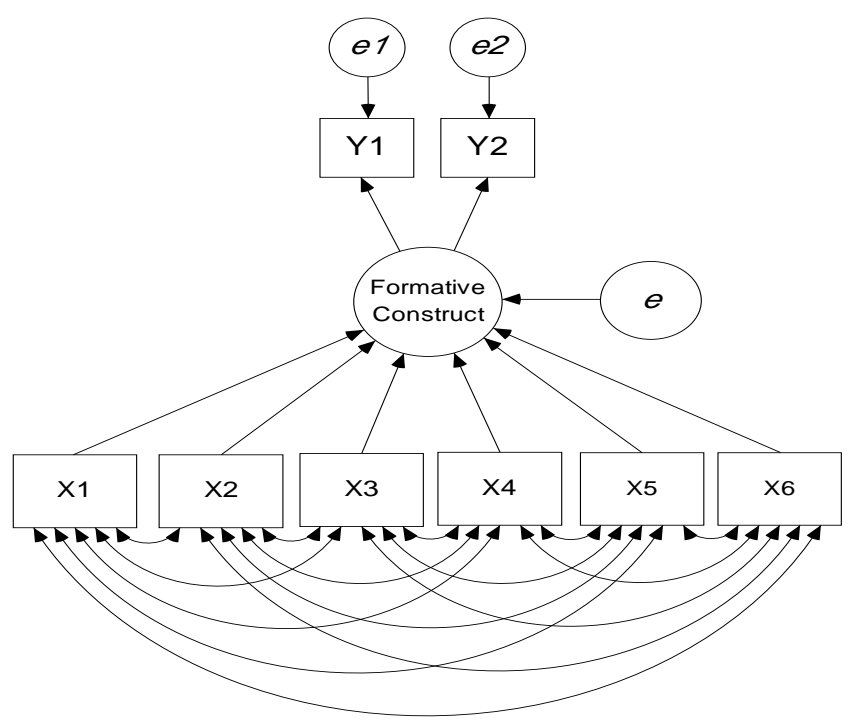

Figure 3: MIMIC Model for Formative Construct with 2 Reflective Items 
As presented in Figure 3, the MIMIC model might be composed of formative indicators $(\mathrm{X} 1, \mathrm{X} 2, \mathrm{X} 3, \mathrm{X} 4, \mathrm{X} 5, \mathrm{X} 6)$ and one or more reflective items (Y1 and $\mathrm{Y} 2)$. The reflective items were items that describe the condition caused by the formative construct. The inclusion of reflective items was necessary for identification purposes (Diamantopoulos and Siguaw, 2006; Diamantopoulos and Winklhofer, 2001; Diamantopoulos, 1999) when covariance structure modelling software packages (e.g. LISRELlinear structural relations, EQS, and AMOSanalysis of moment structures) were used. In this study, the reflective items of organisation fit, organisation sacrifice, and organisation links for the MIMIC model were developed based on studies by Kristof-Brown et al. (2005), Mitchell and colleagues (2001b), and Verquer et al. (2003).

Furthermore, reflective items of community fit, community sacrifice and community links were modified from Cross (2003), and Mitchell and colleagues (2001b). Those reflective items were theoretically an effect of the formative constructs measured. This study used two (2) reflective items for each formative construct of sub-dimensions of job embeddedness. The application of these reflective items in the MIMIC model was previously used by Diamantopoulos and Winklhofer (2001), Diamantopoulos and Siguaw (2006), MacKenzie et al. (2005).

An identified MIMIC model provided information on the relative contribution and significance of individual indicators to the construct. The quality of individual indicators was judged by referring to the $p$-value associated with the parameters of the indicators (the arrows from $\mathrm{X} 1, \mathrm{X} 2, \mathrm{X} 3, \mathrm{X} 4, \mathrm{X} 5$, and $\mathrm{X} 6$ to the formative construct) in the MIMIC model. Indicators were considered valid when they were significantly associated with the construct with a $p$-value equal to or less than 0.05 (Diamantopoulos and Siguaw, 2006). Any items with a non-significant $p$-value were eliminated.

As presented in Appendix 2, this study included six (6) global items and 12 reflective items for the MIMIC model. The global items of organisation fit (OF), organisation sacrifice (OS) and organisation links (OL) were developed based on research by Crossley and colleagues (2007), Mitchell and colleagues (2001b), and Watson-Wyatt (2005). Commu- nity fit (CF), community sacrifice (CS), and community links (CL) dimensions were adapted from concepts developed by Cross (2003), and Mitchell and colleagues (2001b).

\section{Participants}

The total participants involved in this study were 151 participants from Executive MBA students at Universitas Gadjah Mada, Yogyakarta. They were working for a variety of companies, particularly the banking industry. Thus, it was a good sample since the participants came from different backgrounds. Of the 151 questionnaires conveniently distributed, 145 were fully completed and utilised for the study $(n=145)$.

\section{Results] Step One}

This research used 0.9 point of inter-correlation as a sign of very high multicollinearity that may result in serious problem of redundant information and influence a predictability power of a model. The 0.90 point is a common value usually used as a cut off point (Hair et al., 2006; Grewal et al., 2004; Mason and Perreault, 1991). The statistics program utilised in this analysis was SPSS 15 (SPSS-Inc., 2006).

The analysis showed that no items to measure dimension of job embeddedness that is organisation fit, organisation sacrifice, organisation links, community fit, community sacrifice and community links were highly intercorrelated. Thus, all items were carried over to the next step.

\section{Step Two}

In this step, the quality of measures retained from Step One were further analysed by correlating them with related global items. The analysis showed that items measuring organisation fit, organisation sacrifice, and organisation links were statistically correlated with related global items. All items measuring community fit and community links were also correlated significantly with the related global items. There was one item (CS3) measuring community sacrifice was correlated insignificantly

\footnotetext{
${ }^{1}$ Due to space limitation, the statistical analysis of Step One and Step Two were not presented in this paper. For the Step Four, only the final model was presented.
} 
with the global item for community sacrifice. This item was removed and left out for further analysis.

\section{Step Three}

In this step, the items retained from the previous step (Step Two) were further analysed by utilising Multiple Indicators and Multiple Causes (MIMIC) model estimation. The model contained two reflective measures. The inclusion of reflective items is necessary for identification purposes (Diamantopoulos and Siguaw, 2006; Diamantopoulos and Winklhofer, 2001; Diamantopoulos, 1999) when covariance structure modelling software packages (e.g. LISRELlinear structural relations, EQS, and AMOSanalysis of moment structures) are used. This research used two reflective items for each formative construct of dimensions of job embeddedness. The application of two reflective items in the MIMIC model was previously done by Diamantopoulos and Winklhofer (2001), Diamantopoulos and Siguaw (2006), MacKenzie et al. (2005) and produced adequate results.

The goodness of fit of the (SEM) MIMIC model was assessed using several criteria as suggested by researchers such as Arbuckle (2006a), Bentler (1990), Breckler (1990), Byrne (2001), Hair and colleagues (2006), and Medsker et al. (1994). This study employed absolute fit indexes and incremental fit index. The absolute indexes used were chisquare $\left(\mathrm{x}^{2}\right)$, goodness-of-fit index (GFI), and Root Mean Square Error of Approximation (RMSEA). The incremental index utilised was the comparative fit index (CFI).

Table 1: Criteria for Assessing Goodness of Fit

\begin{tabular}{ll}
\hline \multicolumn{1}{c}{$\begin{array}{c}\text { Goodness of Fit } \\
\text { Indices }\end{array}$} & \multicolumn{1}{c}{ Cut Off } \\
\hline a. Chi-square & $\begin{array}{l}\text { Relatively small } \\
\text { and/or statistically } \\
\text { insignificant }\end{array}$ \\
b. Probability ( $p$-value) & $>=0.05$ \\
c. RMSEA & $<=0.08$ \\
d. GFI & $>=0.90$ \\
e. CFI & $\begin{array}{l}\text { Close to or higher } \\
\text { than } 0.95\end{array}$ \\
\hline
\end{tabular}

Table 1 described the criteria applied to assess the model goodness of fit. The model was considered fit when it showed a low or an insignificant chi-square $\left(\mathrm{x}^{2}\right)$ value, a RMSEA of 0.08 or lower, a GFI of greater than 0.90, and a CFI of close to 0.95 or higher than 0.95 (Byrne 2001; Hair et al., 2006; Arbuckle, 2006a; Medsker et al., 1994). In this step, the evaluation was applied to the measurement model. The individual items were not evaluated at this point. All items were carried forward to the next step (step 4) if the model provided a good fit.

Amos 7 (Arbuckle, 2006b) was employed to estimate the parameters in the measurement models. The reason for utilising Amos was mainly because this software package provides a user-friendly graphical interface. The estimation method was maximum likelihood (MLE). The MLE is a default method and commonly used for doing SEM.

\section{MIMIC model of organisation fit}

Figure 4 showed the MIMIC model estimation of organisation fit. The MIMIC model estimation of organisation fit was adequate according to the goodness of fit criteria suggested. The chi-square was insignificant with 0.148 (higher than 0.05) $p$-value. RMSEA of the model was 0.066 far below the cut-off value. GFI and CFI were also sufficient with value of 0.986 and 0.995 respectively.

\section{MIMIC model of organisation sacrifice}

The model fit of organisation sacrifice was reported in Figure 5. All indexes were adequate according to the predetermined criteria. The chi-square was insignificant ( $p$-value 0.097). RMSEA, GFI, and CFI of the model were also favourable.

\section{MIMIC model of organisation links}

Figure 6 showed that the chi-square of organisation links for MIMIC model was insignificant ( $p$-value 0.429). The value of RMSEA was 0.000 , GFI was 0.991, and CFI was 1.000. Based on the cut-off values suggested, the model was adequately fit, and all items were further analysed in Step Four.

\section{MIMIC model of community fit}

Based on the cut-off values suggested, the MIMIC model of community fit (Figure 7) was 
robust. The chi-square was statistically insignificant. The RMSEA value was below the cutoff point. GFI and CFI were also acceptable with values of 0.999 and 1.000 respectively. Thus, all community fit items were further analysed in Step Four.

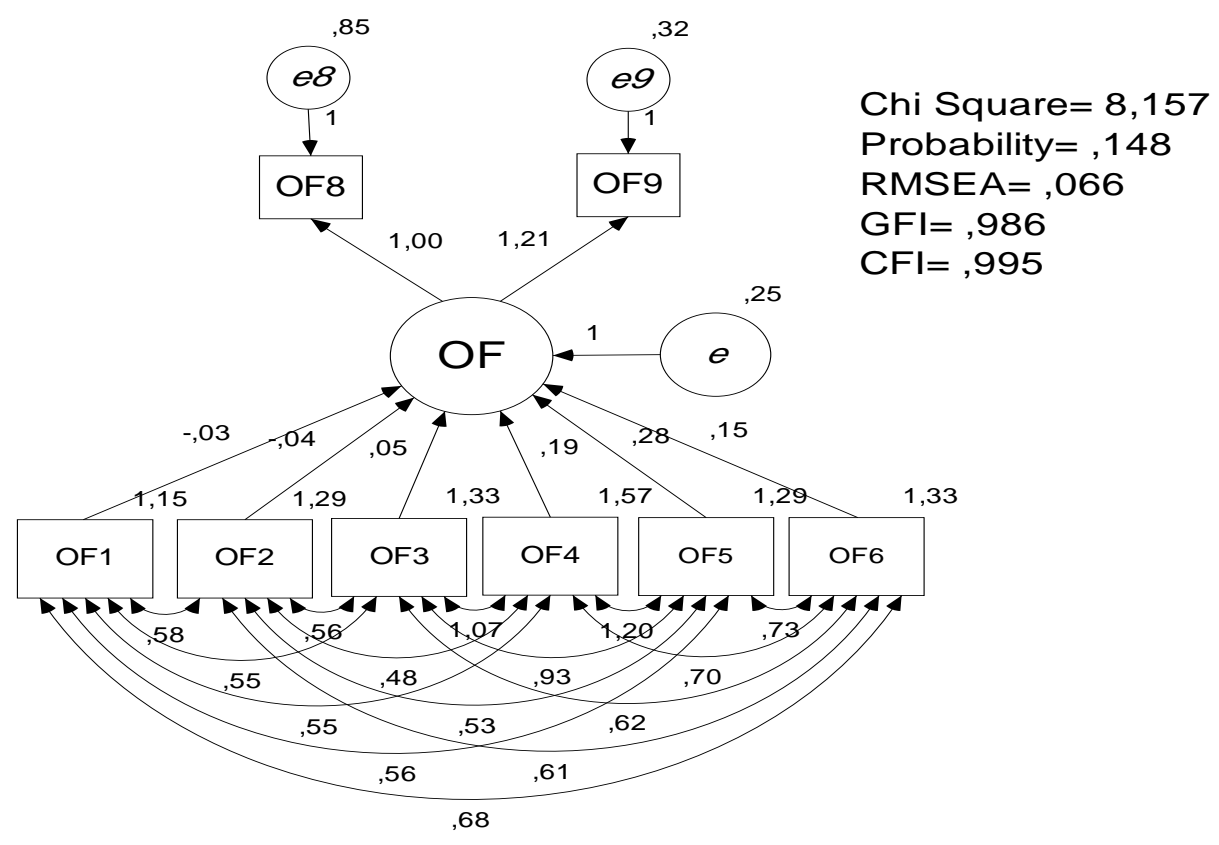

Figure 4: MIMIC Model Organisation Fit

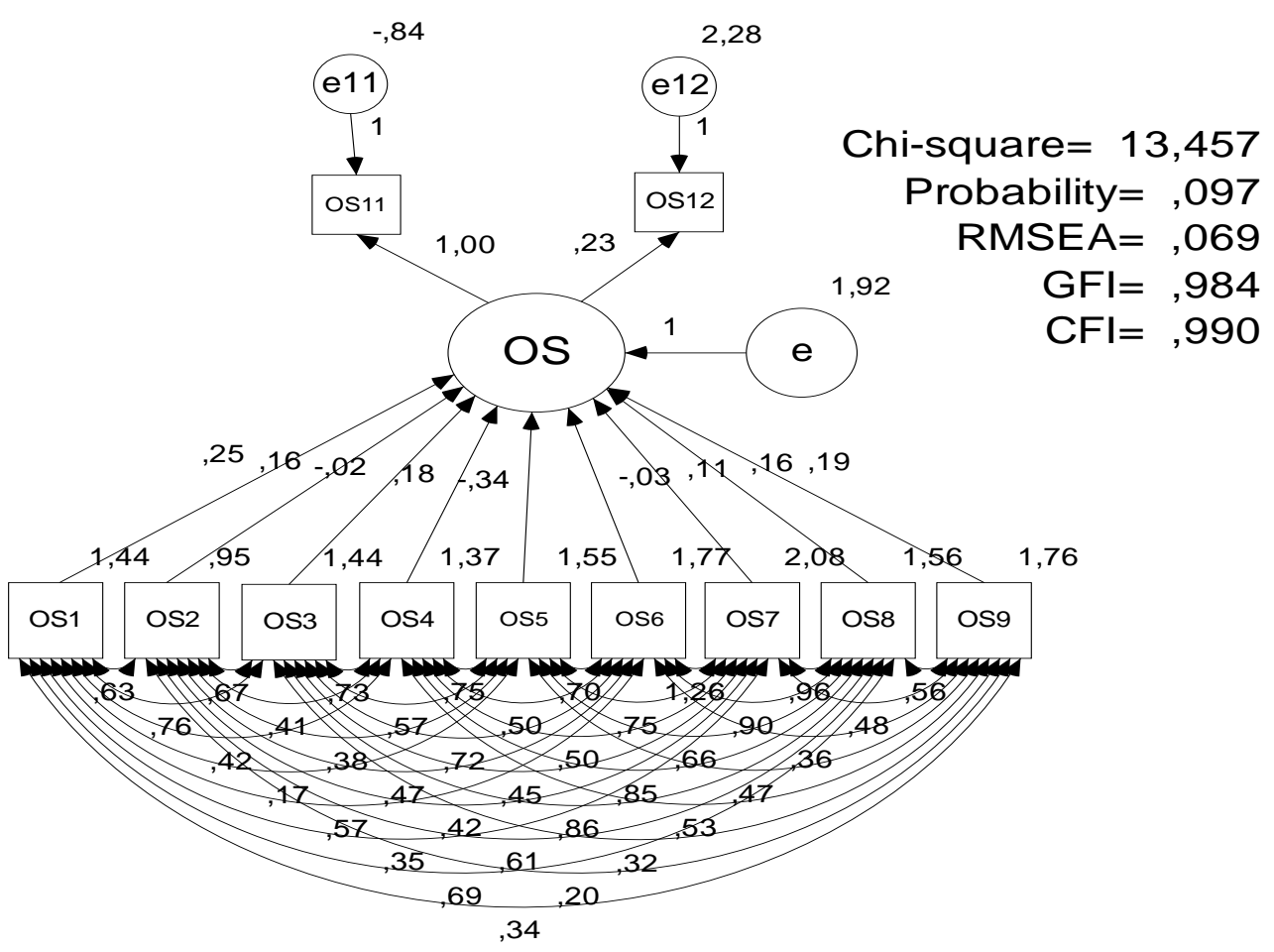

Figure 5: MIMIC Model of Organisation Sacrifice 


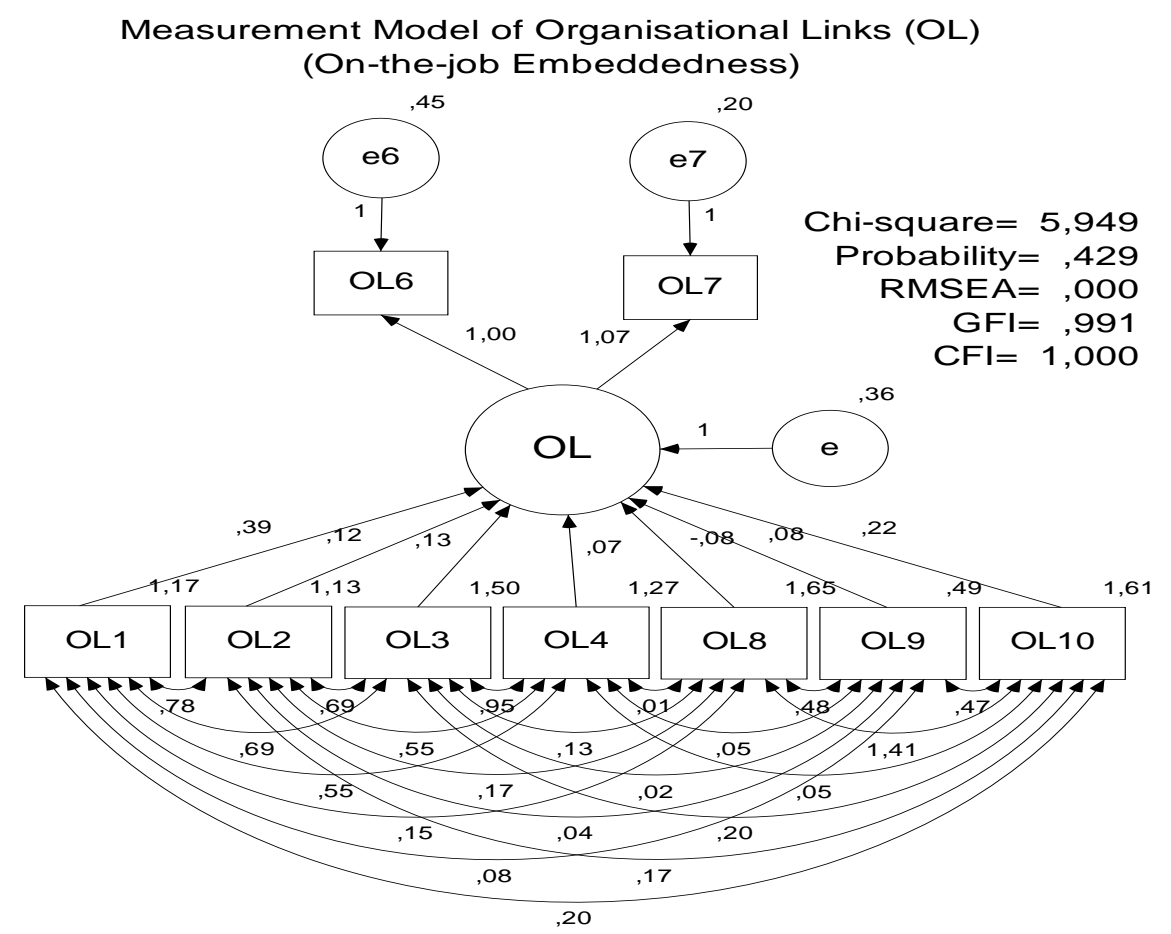

Figure 6: MIMIC Model of Organisation Links

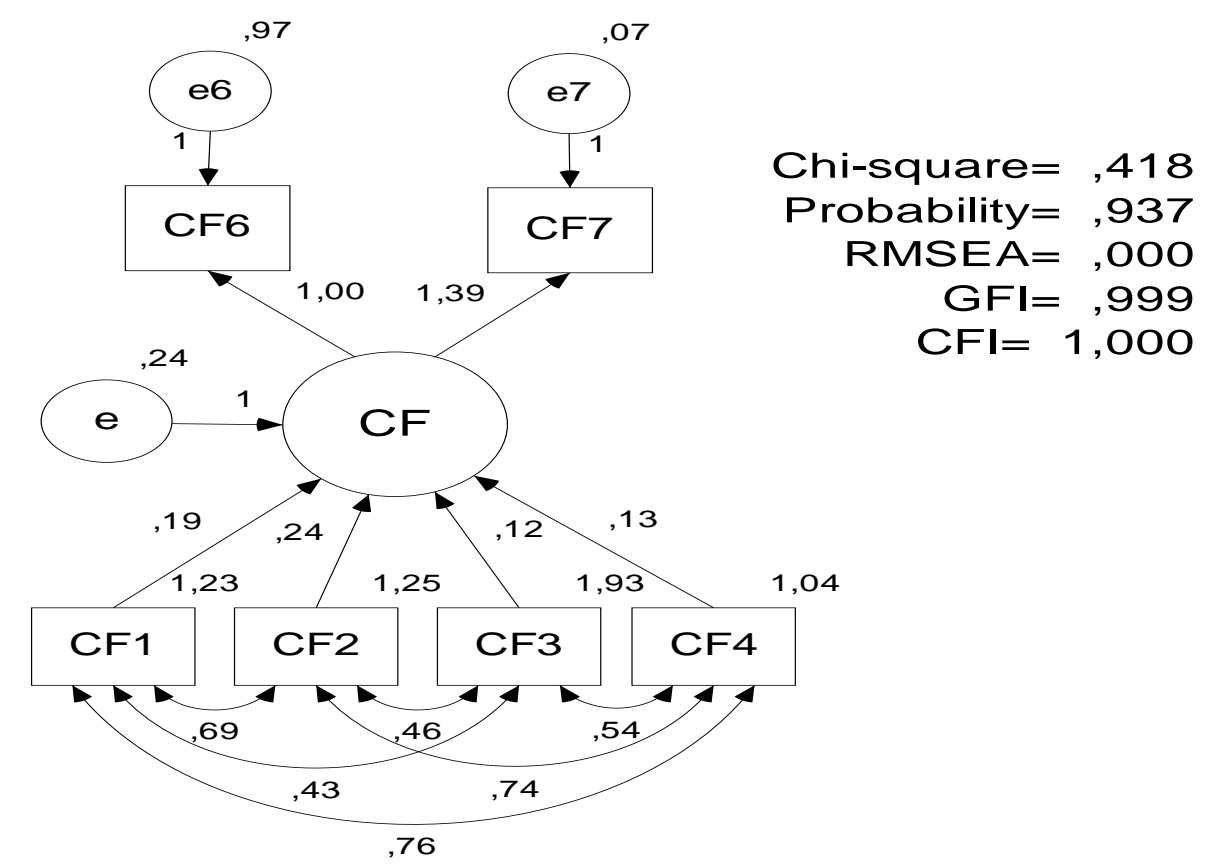

Figure 7: MIMIC Model of Community Fit

\section{MIMIC model of community sacrifice}

The MIMIC model of community sacrifice can be observed in Figure 8. One item, CS3, was not included in the model because the indicator was dropped in Step Two. The model was fit with chi-square value of 4.788 , statistically insignificant, and RMSEA value of 0.064 .

The values of GFI and CFI were 0.989 and 0.993 respectively. Based on the fit model criteria, all community sacrifice items were further analysed in Step Four. 


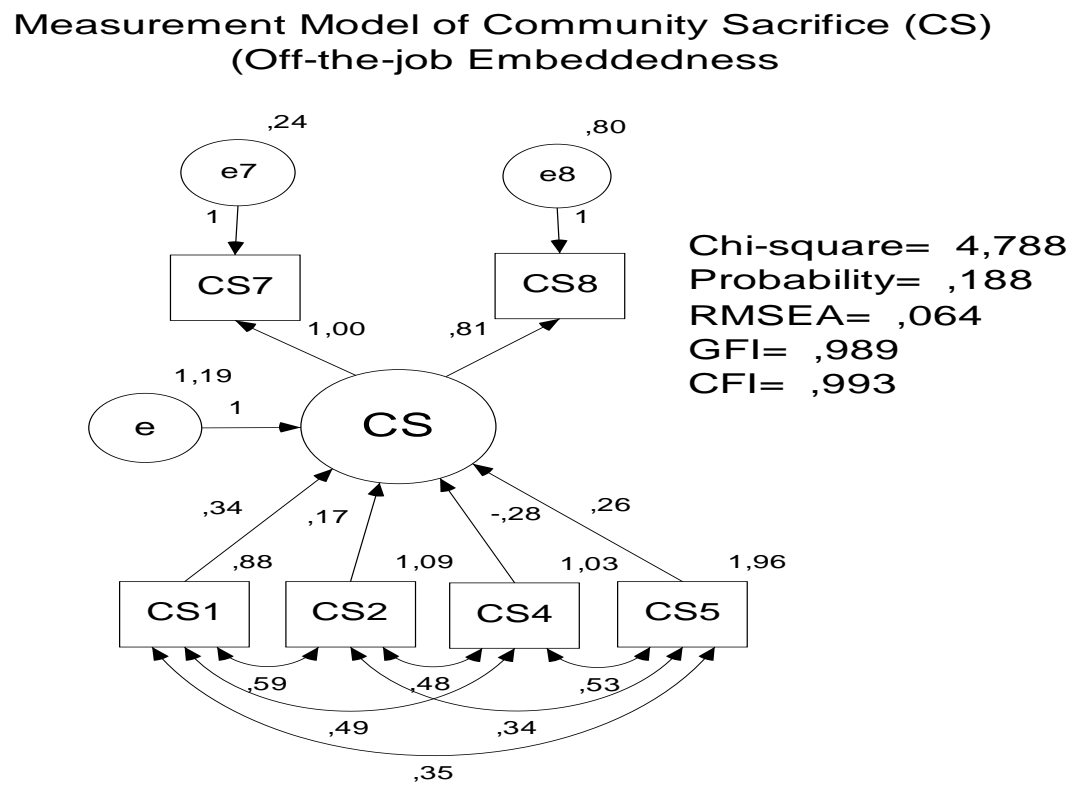

Figure 8 MIMIC Model of Community Sacrifice

\section{MIMIC model of community links}

Figure 9 reported the model fit of community links. The Figure showed that the chi-square value was statistically insignificant. The RMSEA and GFI values were adequate. Unfortunately, even though the value of CFI was fairly high (0.941), but it was still well below 0.95. Based on the CFI value suggested for model fit, all community links items might be dropped. However, further analysis was conducted to double check whether any individual item was statistically significant.

Measurement Model of Community Links (CL)

(Off-the-job Embeddedness)

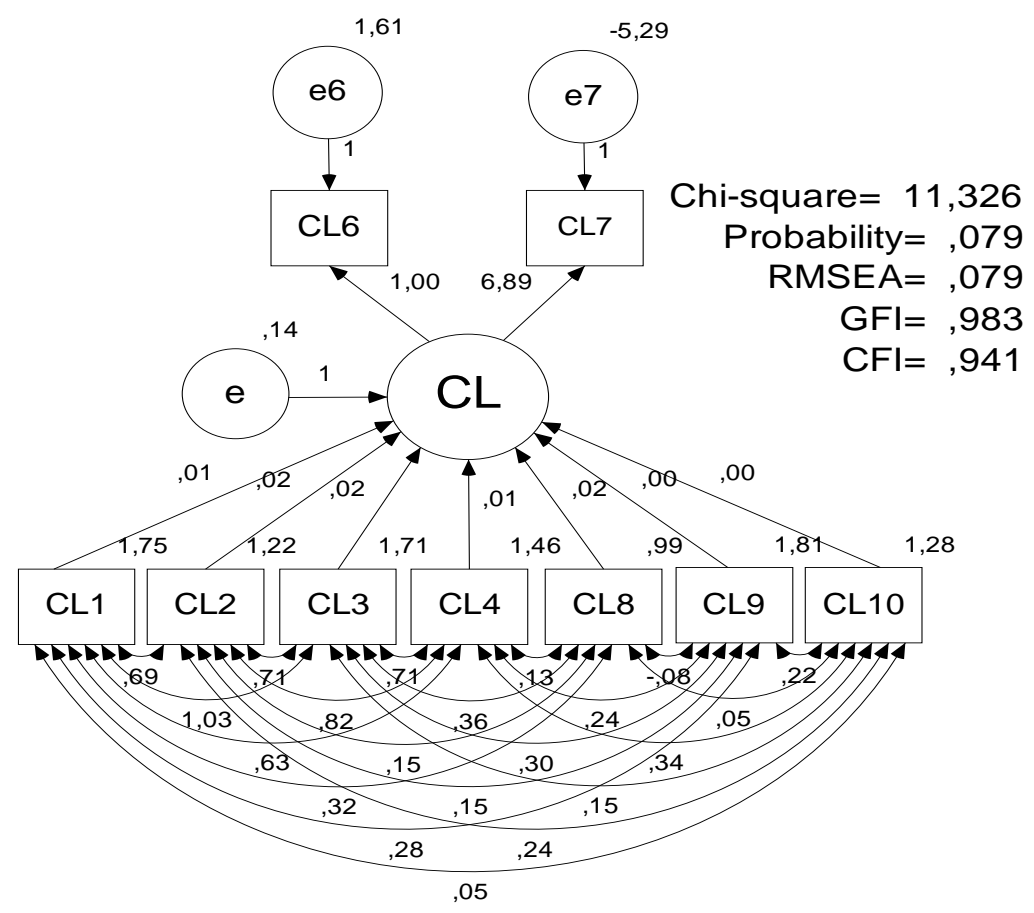

Figure 9 MIMIC Model of Community Links 
Step Four: Assessment of Individual Items Quality

This step was taken to evaluate the validity of on-the-job and off-the-job embeddedness individual items. Following Anderson (1987), a typical $0.05 p$-value of the un-standardised regression weights or coefficient values was applied to assess the significance of individual items structural parameter. In this case, the structural parameters were the numbers that describe the magnitudes of the effects of indicators on the construct measured (Edwards and Bagozzi, 2000). For instance, Figure 10 showed the structural parameter of OF4 on $\mathrm{OF}$ was 0.21 . Thus, the effect of OF4 on OF was 0.21 .

Furthermore, reflective indicators, Y1 and $\mathrm{Y} 2$, were used to make the model identified and therefore the goodness of fit of the measurement model could be identified. So, the structural parameters or the effect of OF on Y1 and Y2 were not analysed. The evaluation of items quality was based on the $p$-value. When the $p$-value associated with the parameters of on-the-job and off-the-job embeddedness items in the MIMIC model estimation were not significant or above 0.05 , they were eliminated. The analysis was performed step by step, starting from the highest or insignificant $p$ value, until all items were statistically significant. In this report, only the final model was presented.

\section{Assessment of organisation fit individual items}

Figure 10 and the un-standardised regression weights (Table 2) showed that three items, namely OF4, OF5, and OF6, hold significant parameters/coefficients of $0.21,0.27$, and 0.13 respectively. The $p$-values were below 0.05 . Those items could be included in the questionnaire to collect data. The regression weights of $\mathrm{OF} 4$, OF5, and OF6 to OF, and the $p$-value (significant level) were shown in Table 2.

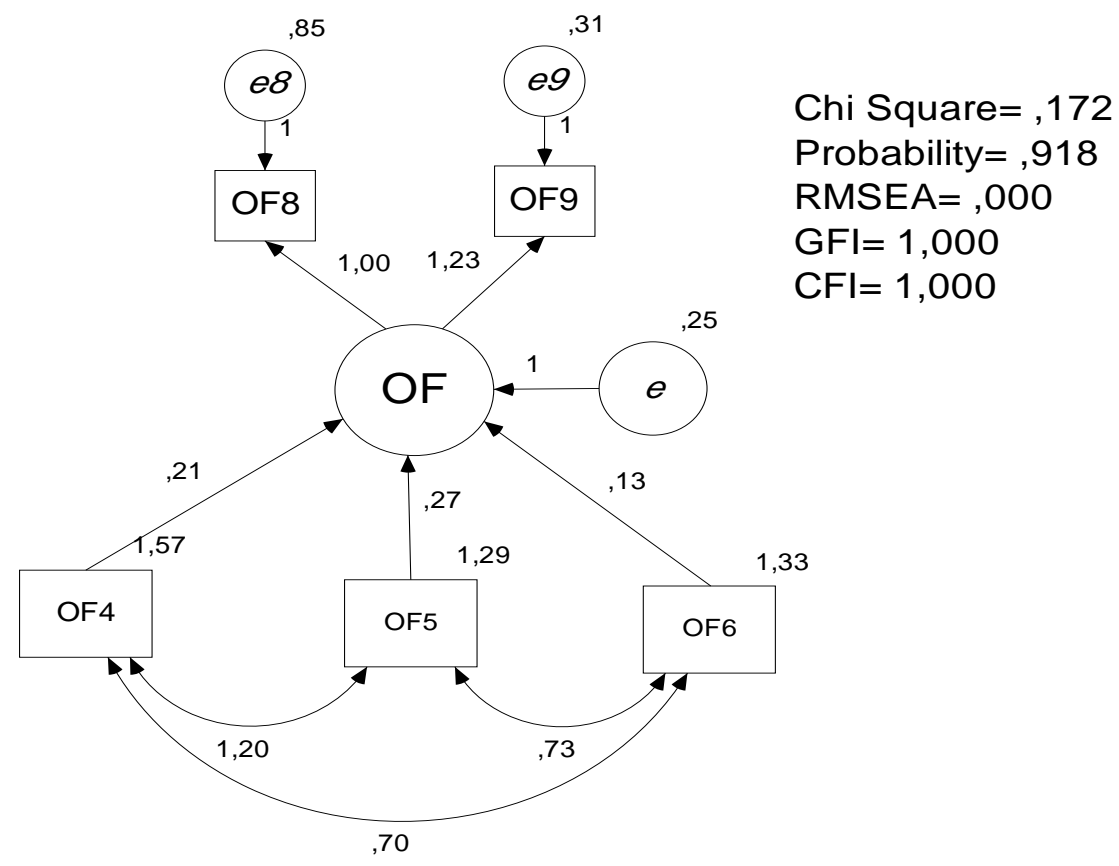

Figure 10: Validity of Organisation Fit Individual Items

Table 2: Regression Weights of Organisation Fit

\begin{tabular}{llllllll}
\hline & & & Esimate & S.E. & C.R. & P & Label \\
\hline OF & $\leftarrow$ & OF4 & 0.212 & 0.083 & 2.554 & 0.011 & par_3 \\
OF & $\leftarrow$ & OF5 & 0.275 & 0.099 & 2.779 & 0.005 & par_4 \\
OF & $\leftarrow$ & OF6 & 0.128 & 0.058 & 2.207 & 0.027 & par_7 \\
OF8 & $\leftarrow$ & OF & 1.000 & & & & \\
OF9 & $\leftarrow$ & OF & 1.226 & 0.163 & 7.543 & $* * *$ & par_1 \\
\hline
\end{tabular}


Assessment of organisation sacrifice individual items

Figure 11 and the regression weights, Table 3, described the measurement model and significant organisation sacrifice individual items. There were four items with significant parameter values namely OS1, OS5, OS8, and OS9. The regression weights (structural paths) of OS1, OS5, OS8, and OS9 to OS were reported in Table 3.

\section{Assessment of organisation links individual items}

There were three organisation links items reported as statistically significant, namely OL1, OL3, and OL10. The model could be observed in Figure 12. The structural parameters for OL1, OL3, and OL10 were 0.46, 0.19, 0.17 respectively. The parameters of the regression weights of OL1, OL3, and OL10 items to OL were presented in Table 4.

\section{Assessment of community fit individual items}

Figure 13 and the regression weights, Table 5, indicated that three items, namely CF1, CF2,
CF3, were statistically significant because their $p$-value were below 0.05. Based on the predetermined criteria, those items were reasonably included in the final measurement.

The regression weights of $\mathrm{CF} 1, \mathrm{CF} 2$, and $\mathrm{CF} 3$ to $\mathrm{CF}$ were shown in Table 5 below.

\section{Assessment of community sacrifice individ- ual items}

Three community sacrifice individual items were valid. Figure 14 and the regression weights, Table 6 , reported that CS1, CS4, and CS5 were statistically significant. Those items could be included in the questionnaire to collect data. Table 7 below showed the structural paths parameter of CS1, CS4, and CS5 to CS.

\section{Assessment of community links individual items}

As reported previously in Step three, Figure 9, the CFI value of community links measurement model was below the cut-off points. Based on the criteria preset, the model did not provide a good fit. The regression weights in Table 8 also showed unfavourable figures.

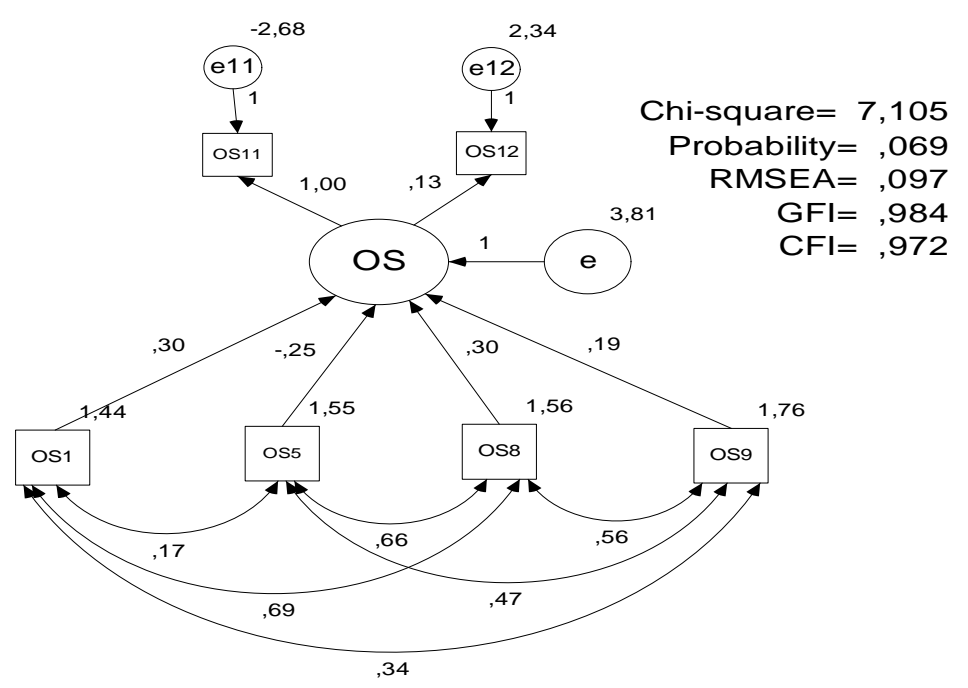

Figure 11: Validity of Organisation Sacrifice Individual Items

Table 3: Regression Weights of Organisation Sacrifice

\begin{tabular}{llllllll}
\hline & & & Estimate & S.E. & C.R. & P & Label \\
\hline OS & $\leftarrow$ & OS1 & 0.299 & 0.083 & 3.626 & $* * *$ & par_5 \\
OS & $\leftarrow$ & OS8 & 0.301 & 0.088 & 3.417 & $* * *$ & par_6 \\
OS & $\leftarrow$ & OS9 & 0.186 & 0.077 & 2.411 & 0.016 & par_7 \\
OS & $\leftarrow$ & OS5 & -0.250 & 0.079 & -3.176 & 0.001 & par_8 \\
OS11 & $\leftarrow$ & OS & 1.000 & & & & \\
OS12 & $\leftarrow$ & OS & 0.132 & 0.193 & 0.687 & 0.492 & par_4 \\
\hline
\end{tabular}




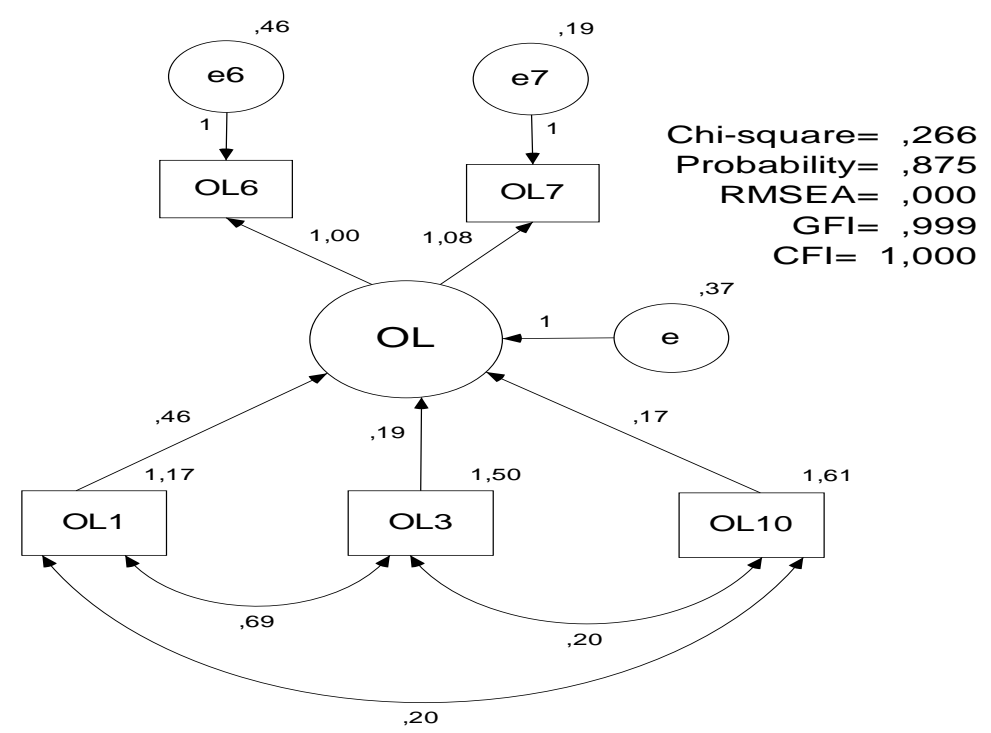

Figure 12: Validity of Organisation Links Individual Items

Table 4: Regression Weights of Organisation Links

\begin{tabular}{llllrrrr}
\hline & & & Estimate & S.E. & C.R. & P & Label \\
\hline OL & $\leftarrow$ & OL3 & 0.188 & 0.057 & 3.294 & $* * *$ & Par_1 \\
OL & $\leftarrow$ & OL10 & 0.172 & 0.048 & 3.616 & $* * *$ & Par_5 \\
OL & $\leftarrow$ & OL1 & 0.465 & 0.072 & 6.479 & $* * *$ & Par_7 \\
OL6 & $\leftarrow$ & OL & 1.000 & & & & \\
OL7 & $\leftarrow$ & OL & 1.085 & 0.099 & 10.934 & $* * *$ & Par_6 \\
\hline
\end{tabular}

Measurement Model of

Community Fit (CF) Valid Items

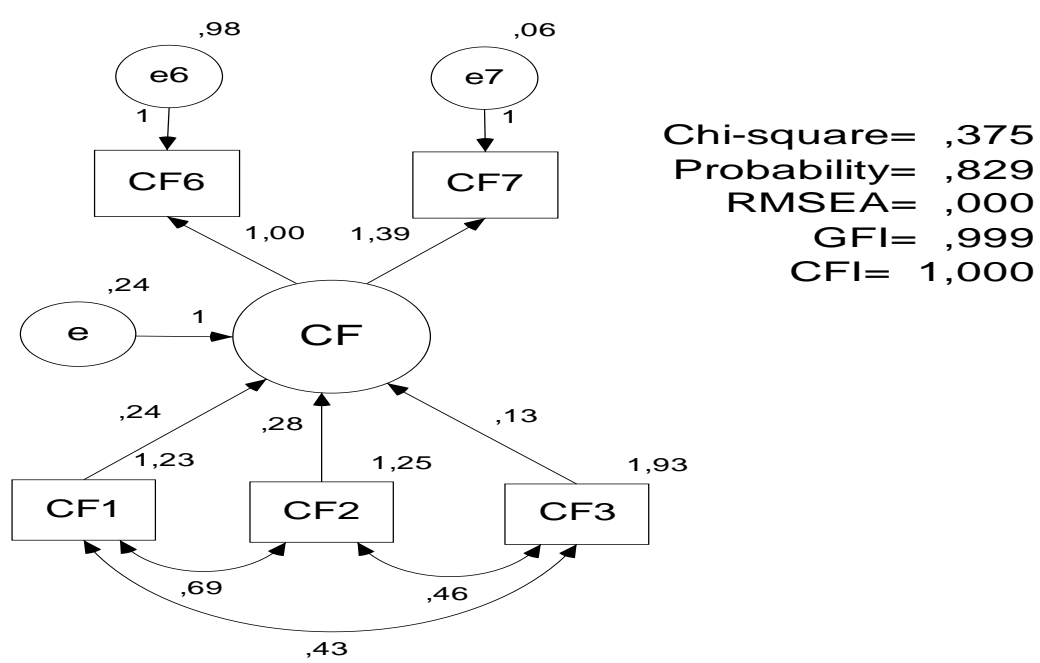

Figure 13: Validity of Community Fit Individual Items

Table 5: Regression Weights of Community Fit

\begin{tabular}{|c|c|c|c|c|c|c|c|}
\hline & & & Estimate & S.E. & C.R. & $\mathbf{P}$ & Label \\
\hline $\mathrm{CF}$ & $\leftarrow$ & CF2 & 0.280 & 0.061 & 4.554 & $* * *$ & par_1 \\
\hline $\mathrm{CF}$ & $\leftarrow$ & CF3 & 0.129 & 0.038 & 3.377 & $* * *$ & par_2 \\
\hline $\mathrm{CF}$ & $\leftarrow$ & CF1 & 0.241 & 0.057 & 4.209 & $* * *$ & par_3 \\
\hline CF6 & $\leftarrow$ & $\mathrm{CF}$ & 1.000 & & & & \\
\hline CF7 & $\leftarrow$ & $\mathrm{CF}$ & 1.392 & 0.196 & 7.100 & $* * *$ & par_7 \\
\hline
\end{tabular}




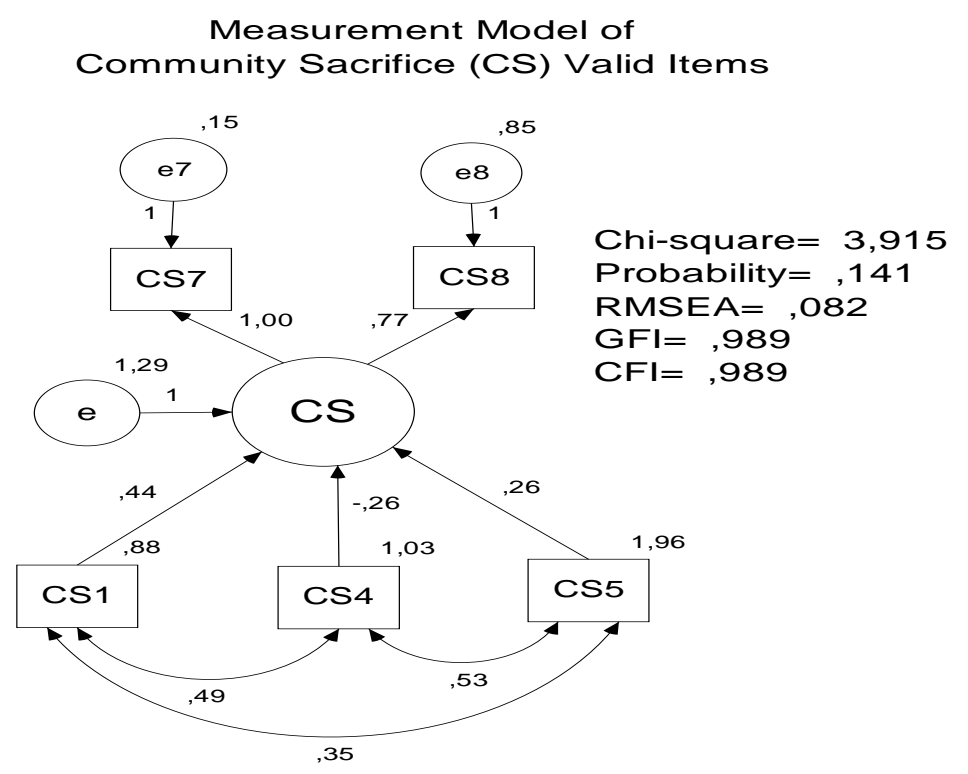

Figure 14: Validity of Community Sacrifice Individual Items

Table 7: Regression Weight of Community Sacrifice

\begin{tabular}{llllllll}
\hline & & & Estimate & S.E. & C.R. & P & Label \\
\hline CS & $\leftarrow$ & CS4 & -0.265 & 0.128 & -2.068 & 0.039 & par_1 \\
CS & $\leftarrow$ & CS5 & 0.261 & 0.078 & 3.352 & $* * *$ & par_2 \\
CS & $\leftarrow$ & CS1 & 0.444 & 0.132 & 3.362 & $* * *$ & par_7 \\
CS7 & $\leftarrow$ & CS & 1.000 & & & & \\
CS8 & $\leftarrow$ & CS & 0.768 & 0.168 & 4.571 & $* * *$ & par_6 \\
\hline
\end{tabular}

Table 8: Regression Weights of Community Links

\begin{tabular}{llllllll}
\hline & & & Estimate & S.E. & C.R. & P & Label \\
\hline CL & $\leftarrow$ & CL2 & 0.019 & 0.058 & 0.336 & 0.737 & par_1 \\
CL & $\leftarrow$ & CL3 & 0.019 & 0.060 & 0.310 & 0.756 & par_2 \\
CL & $\leftarrow$ & CL4 & 0.006 & 0.031 & 0.180 & 0.857 & par_3 \\
CL & $\leftarrow$ & CL8 & 0.020 & 0.064 & 0.313 & 0.754 & par_20 \\
CL & $\leftarrow$ & CL1 & 0.005 & 0.023 & 0.228 & 0.819 & par_27 \\
CL & $\leftarrow$ & CL10 & 0.002 & 0.011 & 0.169 & 0.866 & par_28 \\
CL & $\leftarrow$ & CL9 & 0.002 & 0.009 & 0.244 & 0.807 & par_29 \\
CL6 & $\leftarrow$ & CL & 1.000 & & & & \\
CL7 & $\leftarrow$ & CL & 6.888 & 20.875 & 0.330 & 0.741 & par_10 \\
\hline
\end{tabular}

There was no individual item's parameter that showed an adequate value. The $p$ values in the regression weighs were below 0.05. As a result, all community links items were eliminated and might not be included in the questionnaire for data collection.

The regression weights described in Table 8 showed the significance of structural paths of CL1, CL2, CL3, CL4, CL8, CL9, and CL10 to CL construct.

\section{Discussion}

Traditionally, the quality of job embeddedness measurements was evaluated by applying con- vergent validity (factor loadings) and internal consistency or reliability (Alpha) tests. However, the factor loadings of indicators and the Alpha scores of every dimensions of job embeddedness obtained from previous research significantly varied. The seminal study by Mitchell and associates (2001b), for example, showed that the factor loading might be as high as (0.93) or as low as (0.06). On the other hand, the highest Alpha score was 0.86 for organisation fit (hospital employees sample), and the lowest was 0.50 for community links (hospital employees sample). There were 3 community links indicators in the study done by Mitchell 
and colleagues (2001b) for hospital employees sample showed relatively low factor loadings scores. Those indicators are "My family roots are in this community" (0.06 factor loading), "How many family members live nearby?" (0.07 factor loading), and "How many of your close friends live nearby?" ( 0.13 factor loading).

Those scores indicated that, as a new construct, the measure of job embeddedness is not yet established. Lee et al. (2004) stated:

"....the measures of on- and off-the-job embeddedness are still preliminary and evolving. Although our data on factor structure and internal consistencies produce empirical findings similar to earlier work, these measures are not yet established and standard research instruments".

However, numerous studies (Lee et al., 2004; Crossley et al., 2007; Mallol et al., 2007; Bergiel et al., 2009) consistently used the concepts and measures of job embeddedness developed by Mitchell et al. (2001b). All items were utilised to analyse the relationships between job embeddedness and other variables (Mitchell et al., 2001b; Holtom and O'Neill, 2004; Lee et al., 2004). The adherence to the reflective practice might led to misspecification errors. As a result, organisational policies developed based on the previous research findings that applied the reflective model principles might not be suitable.

This study showed that the valid dimensions of on-the-job embeddedness were organisation fit, organisation sacrifice, and organisation links. On the other hand, the valid dimensions of off-the-job embeddedness are community fit and community sacrifice. Organisation fit dimension was made up of three items; OF4, OF5, OF6. Organisation sacrifice and organisation links dimensions were made up of four items; OS1, OS5, OS8, OS9; and three items; OL1, OL3, OL10; respectively. Further, community fit and community sacrifice dimensions were validly assessed by three measures; CF1, CF2, CF3; and CS1, CS4, CS5, correspondingly. Therefore, the total items to measure on-the-job embeddedness were 10 indicators/items and those to measure dimension of off-the-job embeddedness were six indicators/items.

Compare to Mitchell and colleagues (2001b) the results of this research were sig- nificantly different. This research finding suggested that focus should be given to several dimensions with related items. Community links might not be too relevant in measuring job embeddedness. However, re-testing of the measurements into different research context may be required to promote generalizabilty or stability of the measurements.

The adoption of formative procedures in evaluating job embeddedness measurements offered fruitfull perspectives to consider. The results might differ from those analysed utilizing reflective principles. However, further evaluation on the application of formative procedures is needed to determine the "real" advantages of the application of formative procedures compare to using the reflective practices.

\section{Summary}

The evaluation of indicators/measurements of on-the-job embeddedness and off-the-job embeddedness dimensions by using formative procedures resulted in different conclusion compare to that of evaluation by using convergent validity and reliability test (reflective model). Inconsistent with results obtained from the reflective practices utilised by previous research, formative model procedures applied in this research resulted 16 items for five dimensions valid. No item was valid for community links dimension. However, this research did not attempt to claim that a formative procedure to validate the measurements was superior to a reflective principle. Other tests using different data sets are suggested to observe and find out another insight. Additional yet important considerations should also be judged before deciding to use the result of any evaluation methods.

\section{REFERENCES}

Anderson, JC. 1987. An approach for confirmatory measurement and structural equation modeling of organizational properties. Management Science. 33 (4). 525 541.

Arbuckle, JL. 2006a. Amos 7.0 user's guide. Chicago: SPSS.

Amos (version 7.0) computer program. Amos Development Corporation (SPSS, Inc.). Chicago. 
Bannister, B. and RW. Griffeth. 1986. Applying a causal analytic framework to the Mobley, Horner, and Hollingsworth (1978) turnover model: a useful reexamination. Journal of Management. 12 (3). 433-443.

Bentler, PM. 1990. Comparative fit indexes in structural models. Psychological Bulletin. 107 (2). 238 - 246.

Bergiel, EB., VQ. Nguyen, BF. Clenney, and GS. Taylor. 2009. Human resources practices, job embeddedness and intention to quit. Managerial Research News. 32 (3). 205-219.

Bliss, WG. Cost of employee turnover 2006. Available from http://www.isquare.com/turnover.cfm/. cited September 11, 2006.

Bollen, KA. and R. Lennox. 1991. Conventional wisdom on measurement: a structural equation perspective. $P y$ chological Bulletin. 110 (2). 305-314.

Boshoff, C. and G. Mels. 2000. The impact of multiple commitments on intentions to resign: an empirical assessment. British Journal of Management. 11 (3). 255272.

Breckler, SJ. 1990. Applications of covariance structure modeling in psychology: cause for concern. Psychological Bulletin. 107 (2). 260 - 273.

Byrne, BM. 2001. Structural equation modeling with AMOS: basic concepts, applications, and programming. Mahwah, New Jersey: Lawrence Erlbaum Associates.

Coltman, TR., TM. Devinney, DF. Midgley and S. Venaik. 2007. Formative versus reflective measurement models: two applications erroneous measurement. Available from http://www2.agsm.edu.au/agsm/web.ns f/AttachmentsByTitle/TD Formative_Paper/\$FILE/Formative+Indicator s.pdf. cited November 21, 2007.

Cross, JE. 2003. Conceptualizing community attachmen. Available from http://www.ruralsociology.org/annualmeeting/2003/CrossJennifer.pdf.

Crossley, CD., RJ. Bennett, SM. Jex and JL. Burnfield. 2007. Development of a global measure of job embeddedness and integration into a traditional model of voluntary turnover. Journal of Applied Psychology. 92 (4). 1031-1042.

Cunningham, GB., JS. Fink and M. Sagas. 2005. Extension and further examination of the job embeddedness construct. Journal of Sport Management. 19. 319335.

Dalton, DR., WD. Todor and DM. Krackhardt. 1982. Turnover overstated: the functional taxonomy. The Academy of Management Review. 7 (1). 117-123.

Diamantopoulos, A. 1999. Export performance measurement: reflective versus formative indicators. International Marketing Review. 16 (6). 444-457.

Diamantopoulos, A. and JA. Siguaw. 2006. Formative versus reflective indicators in organizational measure development: a comparison and empirical illustration. British Journal of Management. 17. 263-282.

Diamantopoulos, A. and HM. Winklhofer. 2001. Index construction with formative indicators: an alternative to scale development. Journal of Marketing Research. 38. 269-277.

Edwards, JR. and RP. Bagozzi. 2000. On the nature and direction of relationships between constructs and measures. Psychological Methods. 5 (2). 155-174.

Grewal, R., JA. Cote and H. Baumgartner. 2004. Multicollinearity and measurement error in structural equation models: implications for theory testing. MARKETING SCIENCE 23. (4). 519529.

Griffeth, RW. and PW. Hom. 2001. Retaining valued employees. Thousand Oaks. Sage.

Griffeth, RW., PW. Hom and S. Gaertner. 2000. A meta-analysis of antecedents and correlates of employee turnover: 
update, moderator tests, and research implications for the next millennium. Journal of Management. 26 (3). 463488.

Hair, JF., WC. Black, BJ. Babin, RE. Anderson and RL. Tatham. 2006. Multivariate data analysis. Sixth ed. Singapore. Pearson Education International.

Holtom, BC. and BS. O'Neill. 2004. Job embeddedness: a theoretical foundation for developing a comprehensive nurse retention plan. JONA. 34 (5). 216-227.

Jarvis, CB., SB. MacKenzie and PM. Podsakoff. 2003. A critical review of construct indicators and measurement model misspecification in marketing and consumer research. Journal of Consumer Research. 30. 199-218.

Koys, DJ. 2001. The effects of employee satisfaction, organizational citizenship behavior, and turnover on organizational effectiveness: a unit-level, longitudinal study. Personnel Psychology. 54. 101114.

Kristof-Brown, A., RD. Zimmerman and EC. Johnson. 2005. Consequences of individuals' fit at work: a meta-analysis of person-job, person-organization, person-group, and person-supervisor fit. Personnel Psychology. 58 (2). 281-342.

Law, KS., C. Wong and WH. Mobley. 1998. Toward a taxonomy of multidimensional constructs. Academy of Management Review. 23 (4). 741-755.

Lee, TW., TR. Mitchell, CJ. Sablynski, JP. Burton and BC. Holtom. 2004. The effect of job embeddedness on organizational citizenship, job performance, volitional absences, and voluntary turnover. Academy of Management Journal. 47 (5). 711-722.

MacKenzie, SB., PM. Podsakoff and CB. Jarvis. 2005. The problem of measurement model misspecification in behavioral and organizational research and some recommended solutions. Journal of Applied Psychology. 90 (4). 710730.
Maertz, CP. and RW. Griffeth. 2004. Eight motivational forces and voluntary turnover: a theoretical synthesis with implications for research. Academy of Management Journal. 30 (5). 667-683.

Mallol, CM., BC. Holtom and TW. Lee. 2007. Job embeddedness in culturally diverse environment. Journal of Business and Psychology. 22 (1). 35-44.

March, JG. and HA. Simon. 1958. Organizatons. New York: John Wiley \& Sons.

Mason, CH. and WD. Perreault. 1991. Collinearity, power, and interpretation of multiple regression analysis. Journal of Marketing Reseacrh. 28 (3). 268-280.

Medsker, GJ., LJ. Williams and PJ. Holahan. 1994. A review of current practices for evaluating causal models in organizational behavior and human resources management research. Journal of Management. 20 (2). 439-464.

Mitchell, TR., BC. Holtom and TW. Lee. 2001a. How to keep your best employees: developing an effective retention policy. Academy of Management Executive. 15 (4). 96-108.

Mitchell, TR., BC. Holtom, TW. Lee, CJ. Sablynski, and M. Erez. 2001b. Why People Stay: Using Job Embeddedness to Predict Voluntary Turnover. Academy of Management Journal. 44 (6). 1102-1121.

Mitchell, TR. and TW. Lee. 2001. The unfolding model of voluntary turnover and job embeddedness: foundations for a comprehensive theory of attachment. Research in Organizational Behavior. 23. 189-246.

Mobley, WH. 1982. Some unanswered questions in turnover and withdrawal research. Academy of Management Review. 7 (1). 111-116.

Pinkovitz, WH., J. Moskal and G. Green. 2004. How much does your employee turnover cost? Available from http://www.uwex.edu/CES/cced/public atturn.html . cited September 11, 2006. 
Price, JL. 2004. The development of a causal model of voluntary turnover. In Innovative theory and empirical research on employee turnover, edited by $\mathrm{R}$. Griffeth and P. Hom. Greenwich: Information Age. 3-32.

SPSS (version 15.0) computer program. SPSS, Inc., Chicago.

Staw, BM. 1980. The consequences of turnover. Journal of Occupational Behaviour. 1 (4). 253-273.

Steel, RP. 2002. Turnover theory at the empirical interface: problem of fit and function. Academy of Management Review. 27 (3). 346-360.

Verquer, ML., TA. Beehr and SH. Wagner. 2003. A meta-analysis of relations be- tween person-organization fit and work attitudes. Journal of Vocational Behavior. 63. 473-489.

Watson-Wyatt. 2005. WorkIndonesia 2004/2005: a study of employee attitudes in Indonesia, the keys to what makes Indonesian employees tick: Watson Wyatt Worldwide.

Yao, X., TW. Lee, TR. Mitchell, JP. Burton and CJ. Sablynski. 2004. Job embeddedness: current research and future directions. In Innovative theory and empirical research on employee turnover, edited by R. Griffeth and P. Hom. Greenwich, Connecticut: Age Publishing. 153-187. 
Appendix: A Summary of Measurements

\begin{tabular}{|c|c|c|}
\hline Constructs & $\begin{array}{l}\text { Code of } \\
\text { Items }\end{array}$ & Questions \\
\hline \multirow{6}{*}{$\begin{array}{l}\text { Organisation Fit } \\
\text { Adapted from } \\
\text { Mitchell and col- } \\
\text { leagues (2001b). }\end{array}$} & OF1 & I like the members of my work group. \\
\hline & $\mathrm{OF} 2$ & I have a lot in common with the people I work with. \\
\hline & OF3 & My job utilises my skills and talents well. \\
\hline & OF4 & I like the authority I have at this bank. \\
\hline & OF5 & I like the responsibility I have at this bank. \\
\hline & OF6 & I like the working environment of this bank. \\
\hline \multirow{9}{*}{$\begin{array}{l}\text { Organisation Sacri- } \\
\text { fice } \\
\text { Adapted from } \\
\text { Mitchell and col- } \\
\text { leagues (2001b). }\end{array}$} & OS1 & I have a lot of freedom in this job to get my work done. \\
\hline & OS2 & I feel that people at work respect me a great deal. \\
\hline & OS3 & My promotional opportunities are excellent here. \\
\hline & OS4 & I am well paid for the job I do. \\
\hline & OS5 & This bank gives me great bonuses regularly. \\
\hline & OS6 & The health-care benefits provided by this organisation are excellent. \\
\hline & OS7 & $\begin{array}{l}\text { The retirement benefits (e.g. pension plan) provided by this organisation } \\
\text { are excellent. }\end{array}$ \\
\hline & OS8 & The prospects for continuing employment with this bank are excellent. \\
\hline & OS9 & $\begin{array}{l}\text { It would be hard to leave my job because I have such a great supervisor } \\
\text { (that is, person to whom I am accountable).* }\end{array}$ \\
\hline \multirow{8}{*}{$\begin{array}{l}\text { Organisation Links } \\
\text { Adapted from } \\
\text { Mitchell and col- } \\
\text { leagues (2001b). }\end{array}$} & OL1 & I have strong connections with my \\
\hline & OL2 & $\begin{array}{l}\text { I get along well with my supervisor (or person to whom I am account- } \\
\text { able).* }\end{array}$ \\
\hline & OL 3 & I have excellent ties with many organisations within the Indonesian \\
\hline & ULS & Banking Industry. \\
\hline & OL4 & I have strong relationships w \\
\hline & OL8 & How lo \\
\hline & OL9 & How long ha \\
\hline & OL10 & u worked in the banking in \\
\hline \multirow{4}{*}{$\begin{array}{l}\text { Community Fit } \\
\text { Adapted from } \\
\text { Mitchell and col- } \\
\text { leagues (2001b). }\end{array}$} & CF1 & The weather where I live is suitable for me. \\
\hline & $\mathrm{c}$ & I think \\
\hline & $\mathrm{CF} 3$ & The location where I live offers the leisure activities that I like. \\
\hline & CF4 & I feel comfortable with the home I live in. \\
\hline \multirow{5}{*}{$\begin{array}{l}\text { Community Sacri- } \\
\text { fice } \\
\text { Adapted from } \\
\text { Mitchell and col- } \\
\text { leagues (2001b). }\end{array}$} & CS1 & $\begin{array}{l}\text { People respect me a lot in my community (or neighbourhood) where I } \\
\text { live. }\end{array}$ \\
\hline & $\mathrm{CS} 2$ & My neighbourhood is safe. \\
\hline & CS3 & It is convenient to reach my office from the home I live in. \\
\hline & CS4 & I easily can visit friends from the home I live in.** \\
\hline & CS5 & I live in an area that makes it convenient for me to see my family.** \\
\hline \multirow{7}{*}{$\begin{array}{l}\text { Community Links } \\
\text { Adapted from } \\
\text { Mitchell and col- } \\
\text { leagues (2001b). }\end{array}$} & CL1 & I feel connected to the home I live in. \\
\hline & CL2 & I have strong relationship with many people in the area where I live. \\
\hline & $\mathrm{C}$ & $\begin{array}{l}\text { I feel that my responsibility to my family causes me to stay in the area } \\
\text { where I live.** }\end{array}$ \\
\hline & CL4 & I have great ties with many organisations in the area where I live. \\
\hline & CL8 & What is your marital status? \\
\hline & CL9 & $\begin{array}{l}\text { How many family members (or relatives) live in the same location (or } \\
\text { neighbourhood) as you? }\end{array}$ \\
\hline & CL10 & $\begin{array}{l}\text { How many of your close friends (or people you know well and trust) live } \\
\text { in the same location (or neighbourhood) as you? }\end{array}$ \\
\hline
\end{tabular}

*Added items developed based on Mitchell and colleagues (2001b) and Watson-Wyatt (2005).

**Added items developed from concepts by Mitchell and colleagues (2001b) and Cross (2003).

Sentences in bold were valid items resulted from the evaluation utilizing formative model procedures. 
Appendix 2: Global Items and Questions for MIMIC Model Estimation to Validate Job Embeddedness Measures

\begin{tabular}{|c|c|c|c|}
\hline Constructs & $\begin{array}{c}\text { Code } \\
\text { of } \\
\text { Items }\end{array}$ & Questions & Note \\
\hline $\begin{array}{l}\text { Organisational Fit } \\
\text { Developed from } \\
\text { Crossley et al. (2007), } \\
\text { Kristof-Brown, Zimmer- } \\
\text { man and Johnson (2005), } \\
\text { Mitchell et al. (2001b), } \\
\text { and Verquer, Beehr and } \\
\text { Wagner (2003). }\end{array}$ & $\begin{array}{l}\text { OF7 } \\
\text { OF8 }\end{array}$ & $\begin{array}{l}\text { In general, I really enjoy working at this bank. } \\
\text { The job I do at this bank fulfils most of my } \\
\text { needs. } \\
\text { I am always motivated to come to this bank to } \\
\text { work. }\end{array}$ & $\begin{array}{l}\text { Global Item } \\
\text { Item for } \\
\text { MIMIC } \\
\text { Item for } \\
\text { MIMIC }\end{array}$ \\
\hline $\begin{array}{l}\text { Organisational Sacrifice } \\
\text { Developed from Crossley } \\
\text { et al. (2007), Mitchell et } \\
\text { al. }(2001 \mathrm{~b}) \text {. }\end{array}$ & $\begin{array}{l}\text { OS11 } \\
\text { OS12 }\end{array}$ & $\begin{array}{l}\text { I would sacrifice a lot if I left my job in this } \\
\text { bank. } \\
\text { Too much in my life would be disrupted if I left } \\
\text { this bank. } \\
\text { I am afraid that I would not be able to find a bet- } \\
\text { ter job if I decided to leave this bank. }\end{array}$ & $\begin{array}{l}\text { Global Item } \\
\text { Item for } \\
\text { MIMIC } \\
\text { Item for } \\
\text { MIMIC }\end{array}$ \\
\hline $\begin{array}{l}\text { Organisational Links } \\
\text { Developed from Crossley } \\
\text { et al. (2007), Mitchell et } \\
\text { al. (2001b) and Watson- } \\
\text { Wyatt (2005). }\end{array}$ & $\begin{array}{l}\text { OL5 } \\
\text { OL6 }\end{array}$ & $\begin{array}{l}\text { I feel much attached to this bank. } \\
\text { I can handle my job effectively because I get } \\
\text { strong support from my colleagues and/or su- } \\
\text { pervisor (or person to whom I am accountable). } \\
\text { I am pleased to work at this bank because the } \\
\text { working relationships are positive. }\end{array}$ & $\begin{array}{l}\text { Global Item } \\
\text { Item for } \\
\text { MIMIC } \\
\text { Item for } \\
\text { MIMIC }\end{array}$ \\
\hline $\begin{array}{l}\text { Community Fit } \\
\text { Developed from concepts } \\
\text { by Cross (2003), Mitchell } \\
\text { et al. (2001b). }\end{array}$ & $\begin{array}{l}\text { CF5 } \\
\text { CF6 } \\
\text { CF7 }\end{array}$ & $\begin{array}{l}\text { I really like the place where I live. } \\
\text { I would not leave this community because the } \\
\text { neighbourhood is lovely. } \\
\text { I am pleased to live in this community. }\end{array}$ & $\begin{array}{l}\text { Global Item } \\
\text { Item for } \\
\text { MIMIC } \\
\text { Item for } \\
\text { MIMIC }\end{array}$ \\
\hline $\begin{array}{l}\text { Community Sacrifice } \\
\text { Developed from concepts } \\
\text { by Cross (2003), Mitchell } \\
\text { et al. (2001b). }\end{array}$ & CS7 & $\begin{array}{l}\text { Leaving this community would be very hard for } \\
\text { me. } \\
\text { Leaving this community may result in difficul- } \\
\text { tis to find the same quality of relationships } \\
\text { with neighbours. } \\
\text { My personal life would be disrupted if I left this } \\
\text { community. }\end{array}$ & $\begin{array}{l}\text { Global Item } \\
\text { Item for } \\
\text { MIMIC } \\
\text { Item for } \\
\text { MIMIC }\end{array}$ \\
\hline $\begin{array}{l}\text { Community Links } \\
\text { Developed from concepts } \\
\text { by Cross (2003), Mitchell } \\
\text { et al. (2001b). }\end{array}$ & $\begin{array}{l}\text { CL5 } \\
\text { CL6 } \\
\text { CL7 }\end{array}$ & $\begin{array}{l}\text { I feel much attached to the community I live in. } \\
\text { I prefer to get home soon to stay with my family } \\
\text { rather than spending extra hours at work. } \\
\text { I feel that my home life is more exciting than } \\
\text { work life. }\end{array}$ & $\begin{array}{l}\text { Global Item } \\
\text { Item for } \\
\text { MIMIC } \\
\text { Item for } \\
\text { MIMIC }\end{array}$ \\
\hline
\end{tabular}

